\title{
Development of a medical error scale for nurses in Turkey
}

Havva Öztürk ${ }^{1}$ and İlknur Kahriman ${ }^{1}$

${ }^{1}$ Karadeniz Teknik Universitesi, Trabzon, Turkey. (Correspondence to: Havva Öztürk: ozturkhavva@gmail.com).

\begin{abstract}
Background: Medical errors can have an adverse effect on patients, health care providers and health care organizations. Determining the likelihood of such errors is important to implement appropriate and effective solutions to minimize errors.

Aims: The aim of this study was to develop a valid and reliable scale to evaluate the likelihood of medical errors by Turkish nurses.

Methods: The draft scale (with 94 items) was developed based on primary references and the opinions of nursing experts. Content validity was assessed using 15 nursing experts. Construct validity of the scale was assessed with exploratory and confirmatory factor analyses using 298 nurses at a university hospital in Trabzon, Turkey. To assess test-retest reliability of the scale, another group of 50 nurses were included.

Results: The content validity index of the scale was 0.82 , Cronbach alpha was 0.89 , and item-total correlation values ranged from 0.31 to 0.54. Kaiser-Meyer-Olkin was 0.81, Bartlett test was 5909.75, $\mathrm{P}<0.0001$, and the anti-image correlations ranged between 0.63 and 0.90 . In the four rotations done with varimax rotation, 42 items were excluded because their factor loadings were less than 0.45 . The final scale had 43 items and six subscales: falls, blood and blood products transfusion, medication practices, care practices, communication, and other controlled practices. The six-subscale structure was confirmed by confirmatory factor analysis, and the fit between the scale and its subscales was good.
\end{abstract}

Conclusion: The scale is a valid and reliable tool to collect consistent data on medical errors in the patient-related practices of nurses.

Keywords: medical errors, nursing, patient safety, instrument validation, Turkey

Citation: Öztürk H; Kahriman İ. Development of a medical error scale for nurses in Turkey. East Mediterr Health J. 2020;26(5):525-530. https://doi. org/10.26719/emhj.19.025

Received: 03/12/17; accepted: 18/09/18

Copyright ( C World Health Organization (WHO) 2020. Open Access. Some rights reserved. This work is available under the CC BY-NC-SA 3.0 IGO license (https://creativecommons.org/licenses/by-nc-sa/3.o/igo).

\section{Introduction}

One of the main responsibilities of nurses is to identify unexpected situations and adverse effects in patient care. They also play a key role in the early identification and prevention of risks and in the diagnosis and disclosure of errors in patient care (1). However, it is reported that nurses also make medical errors because of the insufficient number of nurses in medical institutions and the resulting fatigue and burnout (2-6), long working hours (4), heavy workload and high number of night shifts a month $(2,5,6)$, ineffective communication between health care staff $(3,7,8)$, working with critically ill patients, substantial job stress, unfavourable working conditions, and shift work $(3,9,10)$. Nursing staff can also make medical errors because of a lack of knowledge or professional experience, carelessness or negligence (11). Another study reported that reasons for medical errors included lack of training and communication, indifference to the job, lack of motivation and hectic working schedule (12). The most common medical errors made by nurses are errors in medications, infections, falls, communication errors and use of incorrect or inappropriate materials (e.g non-sterile material) $(2,13)$.
Medical errors should be identified and reported as early as possible before they can cause serious harm to people. In addition, the causes should be identified, solutions offered and lessons learnt from such experiences (14).

Valid and reliable measurement tools have been developed and used to help identify the areas in which nurses are more likely to make errors, and the precautions that should be taken to reduce the risk of these errors occurring. A review of the literature in Turkey indicated that several such tools already exist, one of which assesses malpractice in nursing (2). Although the malpractice study discussed some aspects of medical errors, it neglected care practices, which is an important role of nurses. Another published scale in Turkey assesses the attitudes of nurses to medical errors (15) rather than the nursing practices that can lead to medical errors. In a study in the Islamic Republic of Iran, a data collection instrument was used to identify the types and causes of medical error, but the instrument had unsatisfactory validity tests (16). Another survey developed in the United States of America examined the causes of medication errors (17). In addition, national and adapted international scales about the patient safety have been developed in Turkey $(18,19)$. 
In these scales, however, medical errors were discussed either as a single dimension or as a subscale of other dimensions.

The aim of our study was to develop a valid and reliable scale on medical errors in nursing, so that the areas in which errors are more likely to occur can be identified, precautions can be taken against the causes of these errors and the likelihood of these errors occurring can be minimized.

\section{Methods}

\section{Population and sample}

The population consisted of 560 nurses working at a university hospital in Trabzon, Turkey, from which a sample of 298 nurses was drawn to assess the construct validity of the scale through explanatory and confirmatory factor analysis. The sample included nurses who were not on leave at the time of the study and agreed to participate. In the factor analysis, a sample size of 300 is considered good (20) so our sample was very close to good. In addition, Cronbach alpha and item total correlations were tested. To assess test-retest reliability of the scale, a different sample of 50 nurses from the same university hospital were included. A minimum of 50 nurses is suggested for test-retest analysis (21).

\section{Instruments}

The data were collected using an information form and a draft version of the Medical Errors Scale for Nurses. The form contained 13 questions on sociodemographic characteristics: age, marital status, educational status, position, years of working, and years of working at the hospital. The draft scale was developed by the researchers based on several primary references $(1-5,9-11,17,19)$ and the opinions of experts in nursing, nursing management and nursing ethics about medical errors and patient safety.

The draft scale was developed in Turkish and initially consisted of 94 items; the components focused on nursing care practices, medication practices, blood and blood product transfusion, prevention of falls, infection control and communication. A five-point Likert scale was used to rate items as: always (5), often (4), sometimes (3), rarely (2) and never (1). Scores close to 5 on the scale indicated that the nurses were behaving in an appropriate manner with respect to medical errors, while the scores close to 1 indicated that the nurses might not be.

\section{Data collection}

Data on the validity and reliability of the draft scale were collected from 17 to 30 June, 2014. The test-retest data were collected from 15-31 July, 2014. The process of the scale development was in four stages: (i) face validity was assessed with 3 nurses; (ii) face and content validity were then evaluated with 15 specialist nurses; (iii) then construct validity was assessed with exploratory and confirmatory factor analyses with the 298 nurses; and (iv) test-retest reliability of the 43-item scale was assessed with a different group of 50 nurses working at the same university hospital. It was administered on two occasions with a two-week interval in between, and the nurses were asked to complete the scale using a pseudonym.

\section{Data analysis}

For analyses of the scale, the normality of the distribution was evaluated using Kolmogorov-Smirnov tests (one sample) which showed normal distribution.

The validity of the scale was evaluated by exploratory and confirmatory factor analyses. The exploratory factor analysis was performed with Kaiser-MeyerOlkin and Bartlett tests, anti-image correlation, principal components analysis, and varimax rotation. Confirmatory factor analysis was tested with the chisquared test, root mean square error of approximation, comparative fit index and incremental fit index. To evaluate the suitability and compliance of each item to the scale, t-tests and regression analyses were used.

The Cronbach alpha, item total correlations and testretests were calculated to assess the reliability of the scale.

\section{Ethical considerations}

Written permission was obtained from the management of the university hospital on 25 July, 2013 to carry out the study with volunteer nurses whose informed consent had already been obtained. Ethical approval was granted by the Ethics Committee of the Medical Faculty of Karadeniz Technical University on 2 December, 2013.

\section{Results}

\section{Sociodemographic characteristics of the nurses}

Of the 298 nurses who volunteered, 65\% were married, $89 \%$ had a clinical nursing position and $70.5 \%$ had a bachelor's degree in nursing. The mean age and standard deviation (SD) of the nurses was 32.11 (SD 7.6) years, with a mean of 10.24 (SD 7.2) years of work. The mean number of years working at the university hospital was 9.10 (SD 7.4) years.

\section{Face validity and content validity}

For face validity, the scale was given to three nurses, who were asked to assess the comprehensibility and length of the items. In addition, when the group of nursing experts evaluated content validity, face validity was also assessed - whether the items were expressed accurately and clearly. Nine items were revised to improve the comprehension.

Content validity was tested using Lawshe's technique (22). The draft scale was given to 15 experts in nursing who were asked to rate each item as: essential, useful but not essential or not necessary. Based on their opinions, nine items with a content validity ratio less than 0.49 were excluded from the draft scale. This left a scale with 85 items with a mean content validity index of 0.82 . 


\section{Construct validity}

Construct validity was tested with exploratory factor analysis and confirmatory factor analysis. For exploratory factor analysis, principal components analysis and varimax rotation were used. The 85 -item draft scale had a Kaiser-Meyer-Olkin value of 0.81 . The Bartlett test gave a chi-squared value of 5909.75, $P<0.0001$, and the anti-image correlation coefficients ranged between 0.63 and 0.90 . Four rotations were performed with a rotated component matrix, and 42 items were excluded because their loadings were less than 0.45 . The final version of the scale showed no overlap and contained 43 items in six subscales: factor 1 - falls ( $\mathrm{F} 1)$, factor 2 - blood and blood products transfusion (F2), factor 3 - medication practices (F3), factor 4 - care practices ( $F_{4}$ ), factor 5 - communication ( $\mathrm{F} 5$ ), and factor 6 - other controlled practices (F6) (Table 1).

A scree plot graph also showed that the slope plateaued after the sixth point, supporting the finding that the scale consisted of six factors (20). These factors accounted for $51.58 \%$ of the total variance (Table 1 ).

Confirmatory factor analysis was done to confirm the factor structure of the 43 -item scale $(20,23)$. The resulting fit indexes were as follows: chi-squared $=2143.65$, degrees of freedom $=2.52$, root mean square error of approximation $=0.072$, comparative fit index $=0.91$, and incremental fit index $=0.90$. In addition, the independent t-test was performed for the upper and lower $27 \%$ of the sample. The results of the $t$-test were as follows: $t=$ -24.703 for the overall scale, $t=-17.887$ for $\mathrm{F} 1, t=-6.428$ for $F 2, t=-6.829$ for $F 3, t=-12.069$ for $F 4, t=-8.246$ for $\mathrm{F} 5$, and $t=-11.582$ for $F 6$, all with $P$-values $<0.0001$.

\section{Reliability analysis}

The internal consistency of the draft scale was tested using Cronbach alpha, Spearman-Brown coefficient and Guttman coefficient. For the overall scale, the Cronbach alpha was 0.89 , Spearman-Brown coefficient was 0.71 and the Guttman coefficient was 0.70. Item-total correlation values, which are used to test reliability, validity and internal consistency and also as an item analysis or item-discrimination analysis, ranged between 0.31 and 0.54 for all subscales $(P<0.0001)$. The test-retest corre- lation values for the overall scale were $r=0.562$ and $P<$ 0.0001 , whereas $t=0.197$ and $P=0.845$, indicating that the scale does not change over time and is reliable.

\section{Scoring of the scale}

The final version of the scale consisted of 43 items in six subscales: 12 items in $\mathrm{F} 1$, six items in $\mathrm{F} 2$, six items in $\mathrm{F} 3$, eight items in $\mathrm{F} 4$, five items in $\mathrm{F} 5$ and six items in $\mathrm{F} 6$ (Table 1). A score close to 215 (maximum score $43 \times 5$ ) indicated the nurse was disciplined or cautious about medical errors, whereas a score close to 43 (minimum score $43 \times 1$ ) indicated that he/she was not careful about medical errors or was at risk of making medical errors. Mean scores of the total scale and subscales were divided by the number of items to facilitate comparisons, which yielded a value between 1 and 5 for the overall scale and the subscales.

\section{Discussion}

The development of valid and reliable measurement tools in many areas is crucial to achieve consistent and accurate data. For this reason, we aimed to develop a valid and reliable instrument to evaluate the likelihood of medical errors by nurses or to determine whether nurses acted carefully to avoid medical errors in their patient-related practices.

The face validity and content validity of the scale were first studied. Face validity is the extent to which a scale appears to assess the notion being studied (24). It also involves an analysis of the scale's legibility, comprehensibility of the terminology, and length of the statement (23). We asked three nurses in our immediate circle to assess the comprehensibility and length of the items.

For the content validity of the scale, a group of experts was asked to assess both the content validity and face validity of the scale. As a result, nine items were excluded from the 94-item draft scale, and the 85-item scale had a content validity index of 0.82 . This finding suggests an acceptable content validity, because a content validity index of 0.80 and higher is considered acceptable (24).

The scale was also evaluated using exploratory and confirmatory factor analyses. The objective of factor

\begin{tabular}{lcccccc}
\hline $\begin{array}{l}\text { Table } 1 \text { Distribution of the items in the Medical Errors Scale for Nurses by } \\
\text { Factor }\end{array}$ & Variance (\%) & Items & Min. & Max. & $\begin{array}{c}\text { Mean (SD) } \\
\text { Factor } \\
\text { loadings }\end{array}$ \\
\hline F1 - falls & 11.71 & $49-51,55,59-66$ & 2.17 & 5.0 & $4.40(0.52)$ & $0.67-0.51$ \\
F2 - blood and blood product transfusion & 9.19 & $42-47$ & 3.0 & 5.0 & $4.83(0.35)$ & $0.85-0.59$ \\
F3 - medication practices & 8.66 & $21-26$ & 2.33 & 5.0 & $4.79(0.37)$ & $0.80-0.60$ \\
F4 - care practices & 8.46 & $1-5,7,11,12$ & 1.75 & 5.0 & $4.57(0.44)$ & $0.78-0.49$ \\
F5 - communication & 6.87 & $76,78-81$ & 2.60 & 5.0 & $4.76(0.40)$ & $0.74-0.53$ \\
F6 - other controlled practices & 6.67 & $15-17,29,30,39$ & 1.67 & 5.0 & $4.62(0.28)$ & $0.79-0.47$ \\
Total & 51.58 & & 2.99 & 5.0 & $4.49(2.83)$ & $0.85-0.47$ \\
\hline
\end{tabular}

SD: standard deviation. 
analysis is to determine the dimensions that account for specific constructs (25). A prerequisite for factor analysis is a certain amount of correlation between the variables (26). The Bartlett test is used to determine whether variables are sufficiently related to each other. If the $P$-value of this test is less than the level of significance $(P$ $<0.05$ ), the correlation between the variables is sufficient for factor analysis (26). The factor analysis of the 85-item scale showed that the Kaiser-Meyer-Olkin value, a measure used to determine whether the overall group of questions was adequate for factor analysis, was above the acceptable limit, and Bartlett test was highly significant. A Kaiser-Meyer-Olkin value higher than 0.50 suggests that factor analysis of the data can be done $(23,25,27)$. On the other hand, anti-image correlation is a coefficient that tests whether each item/question is suitable for factor analysis, and this coefficient should not be less than 0.50 . If the value of any of the items is less than 0.50 , it should be removed $(23,26,27)$. The anti-image correlation coefficient of the draft scale was more than 0.62. These results indicated that factor analysis could be done. In the varimax rotations, 42 items were excluded from the scale because their factor loadings were too low (less than 0.45). Ideally, factor loadings should be between 0.45 and 0.50 or higher (25).

Thus the final version of the scale consisted of 43 items in six subscales: falls, blood and blood product transfusions, medication practices, care practices, communication and other controlled practices. The sixfactor structure was confirmed by the explained variance and by the fact that the scree plot line plateaued after the sixth point (20) - the six subscales accounted for more than 0.50 of the total variance, which was acceptable in practice (27).

The exploratory factor analysis was followed by confirmatory factor analysis to confirm the constructs that emerged. Confirmatory factor analysis tests whether a previously defined or restricted construct can be confirmed as a model or not (20). Alternatively, it tests the accuracy of a correlation that was previously determined by the researcher (27). All items with significant t-test values were confirmed by the confirmatory factor analysis to be significant. The fit indices were used to test the validity of the model. One of the most common ways to assess fitness is the chi-squared goodness-of-fit (20). Our scale had a fit index of 2.5, suggesting that the items fit the subscales well. In studies with large samples, a chisquared index less than 3 represents an excellent fit (20). The root mean square error of approximation of the path scheme was 0.72 , suggesting that the scale had a good fit. A root mean square error of approximation less than 0.5 represents excellent fit, whereas one less than 0.8 indicates good fit $(20,26)$. The comparative fit index and incremental fit index are two other fit indices. They are known to produce very reliable and impartial predictions when the assumption of a normal distribution is not violated. A comparative fit index and incremental fit index more than 0.95 indicates excellent fit, and one more than 0.90 represents a good or acceptable fit
(28). In this study, the comparative fit index (0.91) and incremental fit index (0.90) suggest good or acceptable fit. All the observed variables in the model indicating the factor structure of the scale and the coefficients of the correlations between the factors were sufficient. Given the fit indices calculated with the confirmatory factor analyses, the construct of the scale was consistent with the data.

The factor analyses were followed by internal consistency and item-discrimination analyses. The difference in the mean scores between the upper and lower $27 \%$ of the sample showed that the items had significant discriminating power and could appropriately distinguish between the upper and lower groups. In other words, the items were highly valid, could appropriately distinguish between nurses' erroneous medical practices, and measured the same behaviour.

The next step was to measure the internal consistency of the 43-item scale to test its validity and determine its homogeneity. Using a single measurement instrument in one session, internal consistency analyses attempt to determine whether items can consistently measure a certain construct (23). In the present study, the Cronbach alpha, Spearman-Brown coefficient, and Guttman coefficient were all 0.70 or higher for the overall scale. The higher these values, the more consistent the items are and the better they can measure the same property (23). An internal consistency coefficient of 0.70 and higher is considered sufficient for the reliability of the test scores $(23,25)$.

Item-total correlation refers to the correlation between the score of an individual item and the overall score of the test (23). In this study, the item-total correlation coefficients of the 43 -item scale were more than 0.31. Certain limit values are accepted to represent standards for interpreting item-total correlation analysis. It is reported that items should have an itemtotal correlation coefficient of 0.30 and higher, as these items can discriminate well between individual items (23). As the coefficients were high in this study, the items belonged to the same construct and the overall scale was reliable.

According to the results of the t-test, which determines whether a property measured by a test changes over time and how consistently the test measures a construct or how similar the answers it obtains are independent of time (21), the scale gave consistent and reliable results when administered at different times. It was therefore reliable in terms of the coefficient of continuity.

\section{Conclusion}

The results of the reliability and validity analyses suggest that the scale is valid and reliable. This scale can thus accurately and consistently measure whether nurses are careful to avoid medical errors, which areas they are more likely to have problems in, and which areas they need to make improvements in. This study can also be used as a guide or reference for future studies on scale development. Our scale is intended for use with nurses 
on an individual level and enables the detection of wider and multidimensional medical errors and error areas in nursing than previously developed scales. Our scale was developed based on the opinions of nurses working in a university hospital. For this reason, it would be useful to evaluate the scale with samples of nurses working in private and public hospitals.

Funding: None.

Competing interests: None declared.

\section{Mise au point d'une échelle d'erreur médicale pour le personnel infirmier en Turquie Résumé}

Contexte : Les erreurs médicales peuvent avoir un impact indésirable sur les patients, les prestataires de soins de santé et les organisations oeuvrant dans ce domaine. Il est important de déterminer la probabilité de ce type d'erreur afin de fournir des solutions appropriées et efficaces pour limiter les erreurs.

Objectifs : La présente étude avait pour objectif de mettre au point une échelle valide et fiable pour évaluer la probabilité d'erreurs médicales commises par le personnel infirmier en Turquie.

Méthodes : Un projet d'échelle (comptant 94 items) a été mis au point à partir des références primaires et de l'opinion d'experts en soins infirmiers. La validité du contenu a été évaluée par 15 experts en soins infirmiers. La validité du construit de l'échelle a été évaluée à l'aide d'analyses factorielles exploratoires et confirmatoires, menées auprès de 298 membres du personnel infirmier d'un hôpital universitaire de Trabzon (Turquie). Pour évaluer la fiabilité de test-retest de l'échelle, un autre groupe de 50 infirmiers a été inclus.

Résultats : L'indice de validité du contenu de l'échelle était de 0,82, l'alpha de Cronbach était de 0,89 et les valeurs de corrélation item-total variaient entre 0,31 et 0,54. La mesure Kaiser-Meyer-Olkin était de 0,81, le test de Bartlett donnait une valeur de $5909,75, p<0,0001$, et les corrélations anti-image se situaient entre 0,63 et 0,90. Dans les quatre rotations effectuées selon la méthode varimax, 42 items ont été exclus, car leur saturation factorielle était inférieure à 0,45. L'échelle finale comptait 43 items et six sous-échelles: chutes, transfusion de sang et de produits sanguins, pratiques médicamenteuses, pratiques de soins, communication et autres pratiques contrôlées. La structure à six sous-échelles a été confirmée par l'analyse factorielle confirmatoire, et l'adéquation entre l'échelle et ses sous-échelles était satisfaisante.

Conclusion : L'échelle est un outil valide et fiable permettant de collecter des données cohérentes sur les erreurs médicales en matière de pratiques des personnels infirmiers auprès des patients.

$$
\text { حوى أوزترك، مقياس للخطأ الطبي لطو اقم التمريض في تركيا }
$$

الخلفية: قد يترتب على الأخطاء الطبية أثر ضار بالمرضى، ومقدمي الرعاية الصحية، وبالمنظلات العاملة في ججال الرعاية الصحية. ومن المهم تحديد

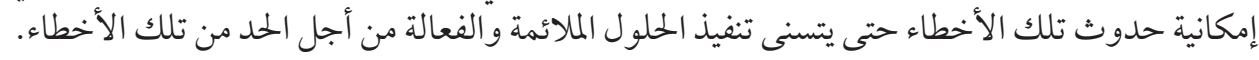
الأهداف: هدفت هذه الدر اسة إلى إعداد مقياس فِّال وموثوق لتقيم احتمالية حدوث الأخطاء الطبية من جانب طو اقم التمريض في تركيا.

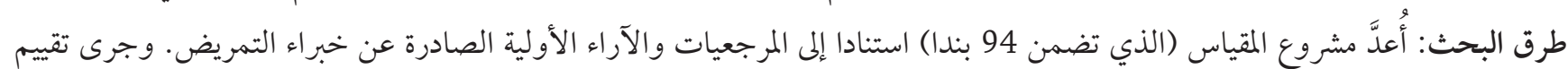

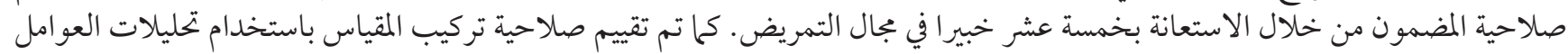

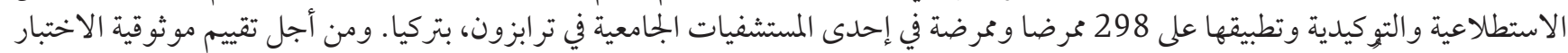

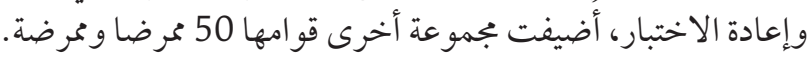

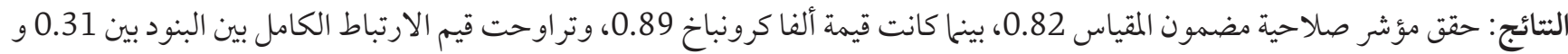

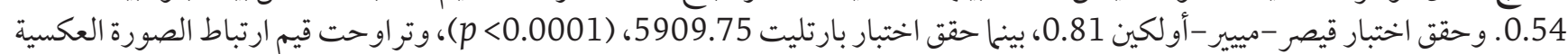

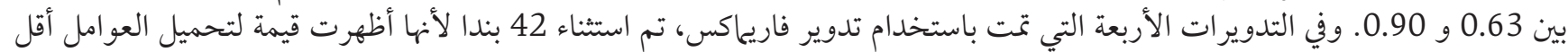

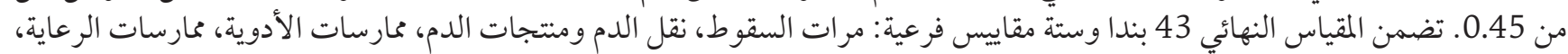

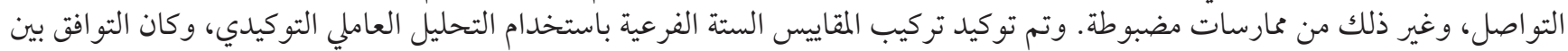

المقياس ومقاييسه الفرعية جيدا. الاستنتاج: يعدُّ المقياس أداة صالحة وموثوقة لجمع البيانات المتسقة حول الأخطاء الطبية التي تحدث في ممارسات طواقم التمريض.

\section{References}

1. $\quad$ Alcan Z, Tekin DE, Civil SÖ. Hasta güvenliği [Patient safety]. Istanbul: Nobel Tıp Kitabevleri; 2012. 
2. Özata M, Altunkan H. Hastanelerde tıbbi hata görülme sıklıkları Tıbbi hata türleri ve tıbbi hata nedenlerinin belirlenmesi: Konya Örneği [Frequency of medical errors at hospitals, determination of medical errors types and medical errors: Konya sample]. Tıp Araştırmaları Dergisi. 2010;8:100-11.

3. Petrova E. Nurses' perceptions of medication errors in Malta. Nurs Stand. 2010;24(33):41-8. https://doi.org/10. 7748/ ns2010.04.24.33.41.c7717

4. Bodur S, Filiz E, Durduran Y. Sağlık personeli ve toplumun tıbbi hatalar ile ilgili görüşlerinin karşılaştırılması [A comparison of medical staff's and community's opinions about medical errors]. Genel Tip Dergisi. 2011;21:123-30.

5. Alemdar DK, Aktaş YY. Medical error types and causes made by nurses in Turkey. TAF PrevMed Bull. 2013;12:307-14. https://doi. org/10.5455/pmb.1-1345816200

6. Kabataş MS, Sevinç F, Sav D. Hemşirelerin tıbbi hata yapma eğilimlerinin incelenmesi [Determining the level of tendency in malpractice among nurses]. Uluslararası Hakemli Hemşirelik Araştırmaları Dergisi. 2014;1:59-74. https://doi.org/10.17371/ UHD.2014210140

7. Fidancı BE, Yıldız D, Konukbay D, Akyol M, Akbayrak N, Hatipoğlu S. Assessment of the malpractice tendencies of nurses working in an educational and research hospital. Int J Caring Sci. 2014;7(1):294-301.

8. Öztürk H, Candaş B, Babacan E. Devlet hastaneleri, toplum ve aile sağlığı merkezlerinde çalışan hemşirelerin yaşadıkları sorunların belirlenmesi [Determining the problems experienced by the nurses working at state hospitals, community and family health care centers]. Sağllk ve Hemşirelik Yönetimi Dergisi. 2015;1:25-36. https://doi.org/10.5222/SHYD.2015.025

9. Zencirci Demir A. Hemşirelik ve hatalı tıbbi uygulamalar [Nursing and malpractice]. Hemşirelikte Araştırma ve Geliştirme Dergisi. 2010;1:67-74.

10. Özata M, Öztürk YE, Cihangiroğlu N, Altunkan H. The development of a scale of malpractice trend in nursing and validity and reliability analysis. Int J Acad Res. 2013;5:57-65.

11. Ertem G, Oksel E, Akbıyık A. Hatalı tıbbi uygulamalar (Malpraktis) ile ilgili retrospektif bir inceleme [A retrospective review about the malpractice applications in medicine]. Dirim Tip Gazetesi. 2009;84:1-10.

12. Andsoy I, Kar G, Öztürk Ö. Hemşirelerin tıbbi hata eğilimlerine yönelik bir çalışma [A study on trends to medical error for nurses]. Sağllk Bilimleri ve Meslekleri Dergisi [J Health Sci Prof]. 2014;1(1):17-27.

13. Adams JL, Garber S. Reducing medical malpractice by targeting physicians making medical malpractice payments. J Empir Leg Stud. 2007;4(1):185-222. https://doi.org/10.1111/j.1740-1461.2007.00087.x

14. Karaca A, Arslan H. Hemşirelik hizmetlerinde hasta güvenliği kültürünün değerlendirilmesine yönelik bir çalışma [A study for evaluation of patient safety culture in nursing services]. Sağlık ve Hemşirelik Yönetimi Dergisi. 2014;1(1):9-18. https://doi. org/10.5222/SHYD.2014.009

15. Güleç D, İntepeler Seren Ş. Tıbbi hatalarda tutum ölçeğinin geliştirilmesi [Developing a scale of attitudes towards medical errors]. Hemşirelikte Araştırma ve Geliştirme Dergisi. 2013;15(3):26-41.

16. Ehsani SR, Cheraghi MA, Nejati A, Salari A, Esmaaeilpoor A, Nejad EM. Medication errors of nurses in the emergency department. J Med Ethics Hist Med. 2013;6:11. PMID:24427488

17. Wakefield DS, Wakefield BJ, Uden-Holman T, Blegen MA. Perceived barriers in reporting medication administration errors. Best Pract Benchmarking Healthc. 1996;1(4):191-7. PMID:9192569

18. Türkmen E, Baykal Ü, Seren Ş, Altuntaş S. Hasta güvenliği kültürü ölçeğinin geliştirilmesi [Development of patient safety culture scale]. Anadolu Hemşirelik ve Sağlık Bilimleri Dergisi. 2011;14(4):38-46.

19. Bodur S, Filiz EA. Survey on patient safety culture in primary health care services in Turkey. Int J Qual Health Care. 2009;21(5):348-55. https://doi.org/10.1093/intqhc/mzpo35

20. Çokluk Ö, Şekercioğlu G, Büyüköztürk Ş. Sosyal bilimler için çok değişkenli istatistik SPSS ve LISREL uygulamaları [SPSS and LISREL applications of multivariate statistics for social sciences]. 14. Bask1 [14th edition]. Ankara: Pegem Akademi; 2014.

21. Sims RL. Bivariate data analysis: A practical guide. Huntington (NY): Nova Publishers, Inc; 2000.

22. Lawshe CH. A quantitative approach to content validity. Pers Psychol. 1975;28(4):563-75.

23. Şencan H. Sosyal ve davranişsal ölçümlerde güvenilirlik ve geçerlilik [Reliability and validity of social and behavioural measures]. Ankara: Seçkin Yayıncılık; 2005.

24. Fawcett AL. Principles of assessment and outcome measurement for occupational therapist and physiotherapist: Theory, skills and application. Chichester: John Wiley \& Sons Ltd.; 2007.

25. Büyüköztürk S. Sosyal bilimler için veri analizi el kitabı [Handbook for data analysis in the social sciences]. 22. Baskı [22nd edition]. Ankara: Pegem Yayıncılık; 2016.

26. Hair JF, Black WC, Barry JB, Rolph EA. Multivariate data analysis. Seventh edition. Upper Saddle River (NJ): Pearson Prentice Hall; 2010.

27. Altunışık R, Çoşkun R, Bayraktaroğlu S, Yıldırım E. Sosyal bilimlerde araştırma yöntemleri [The research methods in social sciences]. 7. Bask1 7th edition]. Sakarya: Sakarya Yayıncılık; 2012.

28. Kline RB. Principles and practice of structural equation modelling. Second edition. New York (NY): Guilford Publications Inc.; 2005. 